\title{
PENYELESAIAN SENGKETA PENGELOLAAN SUMUR TUA SECARA TRADISIONAL OLEH MASYARAKAT DI DESA WONOCOLO BOJONEGORO DITINJAU DARI ASPEK HUKUM
}

\begin{abstract}
Suprapti*
Abstrak

Sumur-sumur minyak di Desa Wonocolo Kecamatan Kadewan Kabupaten Bojonegoro, telah dieksplorasi lebih dari satu abad yang lalu oleh Dordtsche Petroleum Maatschappij. Sumur-sumur tua tersebut banyak yang dinyatakan telah habis, tetapi kenyataannya tidak. Puluhan titik sumur peninggalan Belanda tersebut ternyata masih aktif yang menandakan masih adanya cadangan minyak di kawasan tersebut. Cadangan minyak tersebut sejak tahun 1945 dikelola oleh pemerintah dan sebagian dikelola warga secara tradisional. Minyak yang ditambang oleh masyarakat disetor ke KUD Bogo Sasono dan disetor ke PT Pertamina EP Cepu. Tetapi sejak tahun 2005 mulai masuk orang-orang dari luar Desa Wonocolo yang membeli minyak mentah langsung dari penambang dengan harga lebih tinggi dari harga yang ditetapkan KUD Bogo Sasono. Karena sejak Nopember 2006 tidak ada lagi warga yang menyetor minyak mentah ke KUD Bogo Sasono, maka penyetoran minyak mentah ke PT. Pertamina EP Cepu terhenti. Ditinjau dari aspek hukum, penambangan dan dijual kepada pihak lain untuk kepentingan individu adalah melanggar peraturan perundangan yang berlaku. Studi ini bertujuan untuk merumuskan penyelesaian sengketa pengelolaan sumur tua antara warga setempat dan KUD Bogo Sasono selaku mitra kerja PT Pertamina EP Cepu, sesuai dengan ketentuan peraturan perundangan yang berlaku. Studi ini merupakan doctrinal research dengan pendekatan kasus (Marzuki; 2005). Usulan penyelesaiannya adalah: (1) melakukan sosialisasi peraturan perundangan yang terkait dengan kegiatan penambangan yang boleh dilakukan secara formal dan informal melalui kepala desa yang pada dasarnya harus menyadarkan warga setempat agar tunduk pada hukum; (2) menyelesaikan sengketa antara warga setempat dan KUD Bogo Sasono selaku mitra kerja PT. Pertamina EP Cepu melalui penyelesaian di luar pengadilan; (3) melakukan negosiasi biaya ongkos angkut berdasarkan pertimbangan kepentingan masyarakat luas, bukan sekelompok masyarakat; (4) melakukan penegakan hukum terutama untuk memutus jalur penambang ke pihak luar.
\end{abstract}

Kata kunci: penyelesaian sengketa, pengelolaan sumur tua

Pada tahun 1894 seorang penambang konsesi minyak dari Hindia Belanda bernama Adiraan Stoop untuk pertama kalinya melakukan eksplorasi minyak bumi di kawasan Bojonegoro, Jawa Timur, dan mendirikan perusahaan Dordtsche Petroleum Maatschappij. Setelah lebih dari satu abad sumur-sumur minyak tersebut dieksploitasi, banyak di antara sumur-sumur minyak tersebut yang dinyatakan telah

\footnotetext{
${ }^{*}$ Dosen UPM Soshum ITS
}

jsh Jurnal Sosial Humaniora, Vol 4 No.2, November 2011 
habis. Namun kenyataannya tidak semua sumur peninggalan Belanda tersebut telah habis. Puluhan titik sumur di Desa Wonocolo Kecamatan Kadewan Kabupaten Bojonegoro ternyata masih aktif yang menandakan cadangan minyak di kawasan tersebut masih berlimpah.

Sejak tahun 1945 cadangan minyak di Desa Wonocolo dikelola oleh Pemerintah Indonesia dengan menggunakan pompa sumur atau pompa angguk elektrik. Tetapi sebagian masih dikelola warga setempat secara tradisional dan telah dilakukan secara turun temurun. Penambangan minyak pada sumur-sumur tua di Desa Wonocolo sudah menjadi sumber pencaharian warga yang dikelola oleh kelompok penambang dimana setiap kelompok terdiri dari 10-15 orang. Minyak mentah yang dieksplorasi kelompok penambang disetorkan ke KUD Bogo Sasono, dan selanjutnya KUD Bogo Sasono menyetorkan ke PT. Pertamina EP. Cepu untuk diolah lebih lanjut. Dalam hubungan kerja ini kelompok penambang mendapat biaya ongkos angkut dari KUD Bogo Sasono.

Sejak tahun 2005 kondisi mulai berubah karena masuknya orang-orang dari luar Desa Wonocolo yang membeli minyak mentah dari kelompok penambang dan kemudian mengolahnya sendiri dengan melakukan penyulingan untuk memperoleh hasil produk berupa solar. Dengan demikian di Desa Wonocolo terdapat kelompok penambang, penambang sekaligus juga penyuling dan kelompok penyuling. Akibat kehadiran orang-orang luar tersebut, kelompok penambang tidak lagi menyetor minyak mentah ke KUD Bogo Sasono, dengan alasan harga yang diberikan oleh orang luar lebih tinggi dari harga yang ditetapkan oleh KUD Bogo Sasono. Akhirnya KUD Bogo Sasono menjadi tidak berperan dan sejak Nopember 2006 tidak ada lagi minyak mentah yang disetorkan ke PT. Pertamina EP. Cepu.

Ditinjau dari aspek hukum, eksplorasi yang dilakukan oleh kelompok penambang dan penyuling sejak dari pengangkutan minyak mentah, proses penyulingan hingga menjual minyak mentah, merupakan kegiatan yang diklasifikasikan sebagai illegal transportation, illegal refinery dan illegal sales. Peraturan perundangan yang terkait langsung yang dilanggar meliputi UUD 1945 Pasal 33 ayat 2 dan ayat 3; Undang-undang Nomor 1 Tahun 1970 tentang Keselamatan Kerja Bab III Pasal 3 butir 1; Undang-undang Nomor 22 Tahun 2001 
tentang Minyak dan Gas Bumi Pasal 5, Pasal 7 dan Pasal 9; Peraturan Pemerintah Nomor 82 Tahun 2002 tentang Pengelolaan Kualitas Air; dan Peraturan Menteri Energi dan Sumber Daya Mineral Nomor 01 Tahun 2008 tentang Pedoman Pengusahaan Pertambangan Minyak Bumi pada Sumur Tua Pasal 2 ayat 2. Permasalahan utama yang menyebabkan tidak bersedianya kelompok penambang menjual minyak mentahnya kepada KUD Bogo Sasono adalah karena harga yang diberikan oleh KUD kepada kelompok penambang lebih rendah dibandingkan harga yang diberikan oleh kelompok penyuling. Kelompok penambang dan kelompok penyuling sebenarnya mengetahui dan menyadari sepenuhnya bahwa kegiatan yang mereka lakukan masuk dalam ketegori melanggar hukum, sehingga pengangkutan dan penjualannya harus kucing-kucingan untuk menghindari razia polisi.

Berkaitan dengan permasalahan penambangan dan penyulingan minyak mentah yang dieksplorasi dari sumur tua di Desa Wonocolo yang dikategorikan sebagai kegiatan ilegal tersebut, studi ini bertujuan mencari usulan penyelesaian sengketa antara kelompok penambang dan KUD Bogo Sasono selaku mitra PT. Pertamina EP. Cepu melalui cara-cara yang sesuai dengan ketentuan peraturan perundangan yang berlaku.

\section{Penambangan Sumur Tua di Desa Wonocolo Kecamatan Kadewan Kabupaten Bojonegoro}

Desa Wonocolo Kecamatan Kadewan Kabupaten Bojonegoro (Gambar 1) merupakan salah satu lokasi penambangan minyak sumur tua di Jawa Timur yang dikelola oleh masyarakat secara tradisional. Sebagian besar wilayah Desa Wonocolo adalah hutan jati yang di dalamnya terdapat banyak sumur minyak peninggalan Belanda. Sebagian besar penduduk Desa Wonocolo mempunyai mata pencaharian sebagai penambang. Bahkan PNS, pamong desa, petani dan hampir semua penduduk laki-laki di desa ini mempunyai pekerjaan sampingan sebagai penambang minyak mentah.

Sumur tua di Desa Wonocolo untuk pertama kalinya ditambang pada tahun 1894 oleh perusahaan konsesi minyak Hindia Belanda. Pada tahun 1945 tambang ini di dikelola oleh Pemerintah Indonesia dengan menggunakan pompa angguk elektrik, 
dan sebagian lagi dikelola oleh masyarakat secara tradisional. Setelah lebih dari satu abad dieksploitasi, sumur tersebut dinyatakan telah habis cadangan minyaknya. Tetapi kenyataannya tidak semua sumur peninggalan Belanda tersebut sudah habis atau tidak menghasilkan minyak lagi. Masih ada puluhan titik sumur yang masih aktif dan ditambang oleh warga setempat.

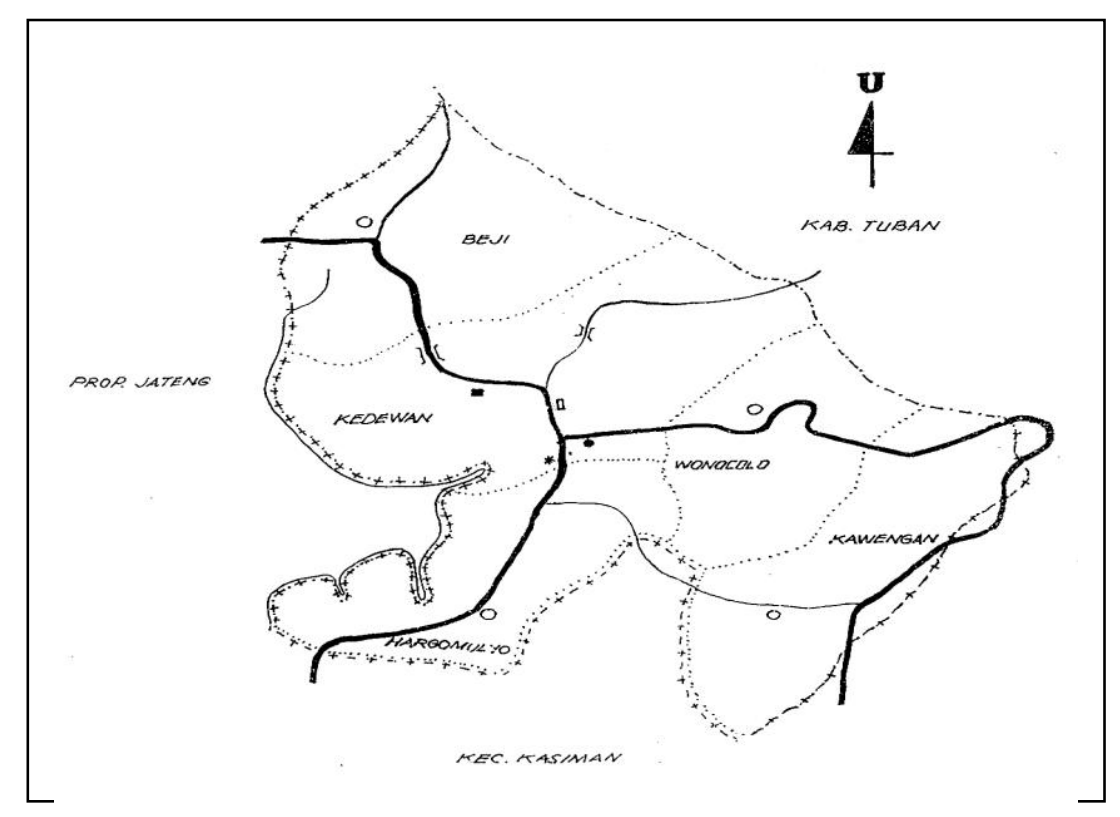

Gambar 1. Orientasi lokasi Desa Wonocolo Kec. Kadewan Kab. Bojonegoro. Sumber: kecamatankadewan.blogspot.com

Ada tiga kegiatan utama yang dilakukan warga dalam mengelola sumur tua, yaitu kegiatan penambangan, penyulingan dan penjualan. Kegiatan penambangan dilakukan oleh kelompok pekerja tambang yang anggotanya terdiri dari 10-15 orang per kelompok, tetapi umumnya terdiri dari 4 orang. Setiap kelompok mengerjakan satu sumur dengan pekerja yang terdiri dari supir truk, penimbel (penambang) dan penyiduk. Para pekerja tersebut tergabung dalam kelompok yang disebut pemborong yang mempuyai jam kerja shift pada siang dan malam hari. Kegiatan penyulingan minyak sebelum tahun 2006 dilakukan oleh PT. Pertamina EP. Cepu. Karena harga yang diberikan oleh Pertamina EP Cepu dinilai oleh warga sudah tidak sesuai lagi, maka banyak warga yang menyuling sendiri minyak mentah yang dihasilkannya. Dengan melakukan penyulingan sendiri, warga bisa mendapatkan pendapatan lebih 
tinggi. Minyak yang sudah disuling, oleh masyarakat dinamakan solar Bojonegoro atau minyak IREX yang dijual bebas secara eceran. Kegiatan penjualan dilakukan oleh penyuling yang menjual minyak hasil sulingan kepada pengecer atau pengepul yang biasanya berasal dari luar Desa Wonocolo. Pengecer menggunakan sepeda motor untuk pengangkutan. Sekali angkut bisa membawa lima jerigen (satu jerigen berkapasitas 35 liter) solar yang dilakukan sampai tiga kali pengangkutan per hari. Ada pula hasil minyak sulingan yang dijual kepada pengepul, tetapi pengepul lebih menyukai membeli dari pengecer, bukan membeli langsung dari penyuling. Pengepul tidak mau mengambil resiko terkena razia polisi karena jual beli minyak mentah dan solar IREX merupakan kegiatan ilegal.

Pada awal 2006 mulai marak terjadi penjualan minyak mentah dari penambang kepada pihak lain di luar KUD Bogo Sasono, sehingga kemampuan menyetorlan minyak mentah dari KUD kepada PT. Pertamina EP. Cepu mulai berkurang, dan pada Bulan Nopember 2006 penyetoran minyak mentah berhenti sama sekali walaupun kontrak kerja antara PT. Pertamina EP. Cepu dan KUD Bogo Sasono belum berakhir. Penyebab utama terhentinya penyetoran minyak adalah karena upah atau ongkos angkut per liter minyak yang diterima penambang masih terlalu rendah. Pada Bulan Januari 2006 imbalan jasa yang diberikan kepada penambang adalah Rp. 354,70/liter atau sekitar Rp. 71.000 per drum (200 liter) yang masih harus dibagi lagi untuk KUD, dana pembangunan daerah, dana pembangunan desa dan upah penambang. Jika penambang menjual kepada pihak luar, mereka bisa mendapatkan Rp. 90.000,- per drum tanpa membagi lagi dengan pihak lain. Walaupun ongkos angkut sudah dinaikkan oleh KUD menjadi Rp. 960,- per liter, warga tetap tidak menyetor minyaknya kepada KUD Bogo Sasono. Hal inilah yang menyebabkan maraknya penjualan minyak mentah secara ilegal kepada pihak lain.

Studi Pengkajian Dampak Pengelolaan Sumur Tua Secara Tradisional Oleh Masyarakat di Wonocolo Field Cepu Region Jawa (2009) menyebutkan beberapa kemungkinan penyebab terjadinya penjualan secara ilegal adalah:

1. Ongkos angkat dan angkut yang diterima penambang setelah dipotong biaya administrasi KUD dan dana pembangunan daerah, masih jauh di bawah harga bila dijual langsung kepada pihak lain di luar KUD Bogo Sasono. 
2. Sebagian penambang mulai bergeser dari hanya sebagai penambang menjadi penambang dan penyuling, sehingga memperoleh keuntungan lebih besar jika dibandingkan dengan menyetor kepada KUD.

3. Adanya pihak lain yang menyebabkan penambang tidak berani menyetor minyak mentah kepada KUD Bogo Sasono. Mereka antara lain adalah pemilik modal dan orang daerah yang sebelumnya merantau dan sekarang sudah kembali ke Desa Wonocolo, yang sudah mempunyai banyak pengetahuan dari dunia luar.

4. Hubungan antara penambang dan dengan KUD Bogo Sasono yang kurang harmonis. Hal ini terlihat dari usaha penambang untuk membentuk KUD lain, yaitu KUD Patra Jasa Jaya. Tetapi KUD ini belum bisa beroperasi karena belum mendapat izin dari Pemerintah sesuai ketentuan Undang-undang Nomor 22 Tahun 2001 tentang Migas.

5. Transaksi minyak mentah hasil sulingan ke luar daerah sangat menguntungkan penambang dan penyuling, tetapi merugikan pemerintah (Pemerintah Kabupaten Bojonegoro dan PT. Pertamina EP Cepu).

Penambangan dan penyulingan minyak mentah di Desa Wonocolo yang dilakukan oleh masyarakat menimbulkan sengketa antara masyarakat (dalam hal ini adalah penambang, penyuling, pengecer dan pengepul) dengan PT. Pertamina EP. Cepu. Ditinjau dari sisi hukum kegiatan yang dilakukan oleh masyarakat adalah melanggar peraturan perundangan yang berlaku yang menyebabkan kerugian pada negara, dalam hal ini adalah PT. Pertamina EP Cepu dan Pemerintah Kabupaten Bojonegoro.

\section{Peraturan Perundangan Yang Berkaitan dengan Penambangan Sumur Tua}

Peraturan dan perundangan yang berkaitan dengan pengelolaan sumur tua secara tradisional oleh masyarakat di Desa Wonocolo adalah:

1. Undang-undang Dasar 1945.

2. Undang-undang Nomor 1 Tahun 1970 tentang Keselamatan Kerja.

3. Undang-undang Nomor 30 Tahun 1999 tentang Arbitrase dan Alternatif Penyelesaian Sengketa.

4. Undang-undang Nomor 22 Tahun 2001 tentang Minyak dan Gas Bumi. 
5. Peraturan Pemerintah Nomor 82 Tahun 2002 tentang Pengelolaan Kualitas Air dan Pengendalian Pencemaran Air.

6. Peraturan Menteri Energi dan Sumber Daya Mineral Nomor 01 Tahun 1008 tentang Pedoman Pengusahaan Pertambangan Minyak Bumi pada Sumur Tua.

Penjelasannya adalah sebagai berikut:

1. Undang-undang Dasar 1945

a. Pasal 33 ayat 2: Cabang-cabang produksi yang penting bagi Negara dan yang menguasai hajat hidup orang banyak dikuasai oleh Negara.

b. Pasal 33 ayat 3: Bumi, air dan kekayaan alam yang terkandung di dalamnya dikuasai oleh Negara dan dipergunakan untuk sebesar-besarnya kemakmuran rakyat.

2. Undang-undang Nomor 30 Tahun 1999 tentang Arbitrase dan Alternatif Penyelesaian Sengketa

a. Pasal 1 ayat 1: Arbitrase adalah cara penyelesaian suatu sengketa perdata di luar peradilan umum yang didasarkan perjanjian arbitrase yang dibuat secara tertulis oleh para pihak yang bersengketa.

b. Pasal 5: Sengketa yang dapat diselesaikan melalui arbitrase hanya sengketa di bidang perdagangan.

c. Pasal 6: Sengketa atau beda pendapat perdata dapat diselesaikan oleh para pihak melalui alternatif penyelesaian sengketa yang didasarkan pada itikad baik dengan mengesampingkan penyelesaian secara litigasi di pengadilan.

3. Undang-undang Nomor 22 Tahun 2001 tentang Minyak dan Gas

a. Pasal 1 angka 1: Minyak bumi adalah hasil proses alami berupa hidrokarbon yang dalam kondisi tekanan dan temperatur atmosfer berupa fasa cair atau padat, termasuk aspal, lilin mineral atau ozokerit, dan bitumen yang diperoleh dari proses penambangan, tetapi tidak termasuk batubara atau endapan hidrokarbon lain yang berbentuk padat yang diperoleh dari kegiatan yang tidak berkaitan dengan kegiatan usaha minyak dan gas bumi.

b. Pasal 1 ayat 2: Gas bumi adalah hasil proses alami berupa hidrokarbon yang dalam kondisi tekanan dan temperatur atmosfer berupa fasa gas yang diperoleh dari proses penambangan minyak dan gas bumi. 
c. Pasal 1 angka 20: Izin usaha adalah izin yang diberikan kepada Badan Usaha untuk melaksanakan pengolahan, pengangkutan, penyimpanan dan/atau niaga dengan tujuan memperoleh keuntungan dan/atau laba.

d. Pasal 5: Kegiatan usaha minyak dan gas bumi terdiri atas:

(1) Kegiatan usaha hulu yang mencakup:

a. Eksplorasi, b Eksploitasi

(2) Kegiatan usaha hilir yang mencakup:

a.Pengolahan, b.Pengangkutan, c. Penyimpanan, d. Niaga

e. Pasal 7 ayat 1: Kegiatan usaha hilir sebagaimana dimaksud dalam Pasal 5 angka 2 dilaksanakan dengan Izin Usaha sebagaimana dimaksud dalam Pasal 1 angka 20.

f. Pasal 7 ayat 2: Kegiatan usaha hilir sebagaimana dimaksud dalam Pasal 5 angka 2 diselenggarakan melalui mekanisme persaingan usaha yang wajar, sehat dan transparan.

g. Pasal 9 ayat 1: Kegiatan usaha hulu dan kegiatan usaha hilir sebagaimana dimaksud dalam Pasal 1 angka 1 dan angka 2 dapat dilaksanakan oleh:

(1) Badan Usaha Milik Negara

(2) Badan Usaha Milik Daerah

(3) Koperasi Usaha Kecil

(4) Badan Usaha Swasta

h. Pasal 9 ayat 2: Bentuk usaha tetap hanya dapat melaksanakan kegiatan usaha hulu.

4. Undang-undang Nomor 1 Tahun 1970 tentang Keselamatan Kerja

Undang-undang Nomor 1 Tahun 1970 bertujuan untuk melindungi pekerja seperti disebutkan dalan Bab III Pasal 3 butir 1, dimana telah ditetapkan syaratsyarat keselamatan kerja seperti: mencegah dan mengurangi kecelakaan; mencegah dan mengurangi bahaya peledakan; memberi alat-alat perlindungan diri pada pekerja; memelihara kebersihan, kesehatan dan ketertiban.

5. Peraturan Pemerintah Nomor 82 Tahun 2001 tentang Pengelolaan Kualitas Air dan Pengendalian Pencemaran Air. 
Peraturan pemerintah Nomor 82 Tahun 2001 antara lain dijabarkan dalam Peraturan Menteri Lingkungan Hidup Nomor 04 Tahun 2007 tentang baku Mutu Air Limbah kegiatan Migas. Khusus untuk Provinsi Jawa Timur, ketetapan mengenai Rancangan Baku Mutu Air Limbah Industri dan kegiatan lainnya sedang dibahas di DPRD Provinsi Jawa Timur untuk di Perda-kan agar mempunyai kekuatan hukum yang mengikat.

6. Peraturan Menteri Energi dan Sumber Daya Mineral Nomor 01 Tahun 2008 tentang Pedoman Pengusahaan Pertambangan Minyak Bumi pada Sumur Tua. Pasal 2 ayat 2:

Dalam hal kontraktor tidak mengusahakan dan memproduksi minyak bumi dari sumur tua, KUD atau BUMD dapat mengusahakan dan memproduksi minyak bumi setelah mendapatkan persetujuan Menteri.

\section{Pembahasan}

Studi ini masuk dalam kategori doctrinal research melalui pendekatan kasus (Marzuki; 2005) dengan cara mengevaluasi kondisi lapangan terhadap UUD 1945, Undang-undang Nomor 1 Tahun 1970 tentang Keselamatan Kerja, Undang-undang Nomor 22 Tahun 2001 tentang Minyak dan Gas Bumi, Peraturan Pemerintah Nomor 82 Tahun 2002 tentang Pengelolaan Kualitas Air, dan Peraturan Menteri Energi dan Sumber Daya Mineral Nomor 01 Tahun 2008 tentang Pedoman Pengusahaan Pertambangan Minyak Bumi pada Sumur Tua.

1. Kajian Terhadap Undang-undang dasar 1945. Minyak dan gas bumi merupakan sumber daya alam strategis yang seharusnya dikuasai oleh Negara, dan dikelola secara maksimal untuk kemakmuran dan ke4sejahteraan rakyat (Pasal 33 ayat 2 dan ayat 3). Dalam hal ini pengelolaan dilakukan oleh KUD Bogo Sasono mitra kerja PT. Pertamina EP. Cepu yang mempunyai 2.765 anggota. Secara legal pengalolaan oleh KUD Bogo Sasono sampai dengan Agustus 2006 tidak bertentangan dengan UUD 1945. Sesudah Agustus 2006 masyarakat tidak lagi menyetorkan minyak mentahnya ke KUD Bogo Sasono, tetapi menjualnya ke pengepul; maka pengelolaan yang dilakukan oleh masyarakat dapat 
dikategorikan menyimpang dari UUD 1945 karena mempunyai konotasi mencari keuntungan pribadi.

2. Kajian Terhadap Undang-undang Nomor 30 Tahun 1999 tentang Arbitrase dan Alternatif Penyelesaian Sengketa. Pasal 1 ayat 1, Pasal 5 dan Pasal 6 Undangundang Nomor 30 Tahun 1999, mengatur penyelesaian sengketa atau beda pendapat antara para pihak dalam suatu hubungan hukum. Para pihak yang bersengketa adalah subyek hukum baik menurut hukum perdata maupun hukum publik. Karena itu sangat besar peluang untuk menyelesaikan sengketa ongkos angkat dan angkut antara KUD Bogo Sasono mitra kerja PT. Pertamina EP. Cepu dan masyarakat Desa Wonocolo yang menambang minyak sumur tua melalui arbitrase. Tetapi penjualan minyak mentah dari penambang kepada penyuling dan penyuling kepada pengecer maupun kepada pengepul tidak dapat dibenarkan.

3. Kajian Terhadap Undang-undang Nomor 22 Tahun 2002 tentang Minyak dan Gas Bumi. Kegiatan penambangan, penyulingan, pengangkutan dan penjualan minyak mentah kepada pihak ketiga, tercakup di dalam substansi Pasal 5 Undang-undang Nomor 22 Tahun 2002; karena itu klausul dalam undangundang ini bisa diberlakukan kepada masyarakat desa Wonocolo yang melakukan penambangan, penyulingan, pengangkutan dan penjualan minyak mentah. Kegiatan penambangan, penyulingan, pengangkutan dan penjualan minyak mentah yang dilakukan masyarakat Desa Wonocolo digolongkan sebagai kegiatan yang melanggar hukum, karena:

a. Tidak memenuhi ketentuan Pasal 7 yang mewajibkan kegiatan usaha tersebut dilengkapi dengan izin usaha.

b. Tidak memenuhi ketentuan Pasal 9 yang menyatakan bahwa kegiatan usaha hulu dan kegiatan usaha hilir dapat dilaksanakan oleh BUMN, BUMD, Koperasi, Usaha Kecil, Badan Usaha Swasta. Dalam kenyataannya kegiatan usaha tersebut dilakukan oleh kelompok perorangan.

4. Kajian Terhadap Undang-undang Nomor 1 Tahun 1970 tentang Keselamatan Kerja. Bab III Pasal 3 butir 1 Undang-undang Nomor 1 Tahun 1970 menyebutkan ketentuan mengenai syarat-syarat keselamatan kerja yang 
bertujuan mengurangi kecelakaan, mencegah dan mengurangi bahaya ledakan; memberi alat-alat perlindungan diri pada pekerja, memelihara kebersihan, kesehatan dan ketertiban. Dalam kenyataannya kegiatan penambangan minyak di Desa Wonocolo mengabaikan semua hal tersebut; seperti menambang dan menyuling sambil merokok; lokasi penyulingan yang terlalu dekat dengan penambangan yang berpotensi menimbulkan bahaya jika gas yang keluar dari sumur tidak terkontrol.

5. Kajian Terhadap Peraturan Pemerintah Nomor 82 Tahun 2001 tentang Pengelolaan Kualitas Air dan Pengendalian Pencemaran Air. Peraturan Pemerintah Nomor 82 Tahun 2001 dijabarkan lebih lanjut dalam Peraturan Menteri Lingkungan Hidup Nomor 04 Tahun 2007 tentang Baku Mutu Air Limbah Kegiatan Migas. Untuk Provinsi Jawa Timur ketentuan mengenai hal ini diatur dalam Rancangan Baku Mutu Air Limbah Industri dan Kegiatan Lainnya yang telah masuk ke DPRD Provinsi Jawa Timur untuk dibahas dan disahkan sebagai Perda. Oleh sebab itu ketentuan mengenai baku mutu air limbah penambangan minyak mentah masih harus menunggu sampoai disahkannya rancangan perda tersebut.

6. Kajian Terhadap Peraturan Menteri Energi dan Sumber Daya Mineral Nomor 01 Tahun 2008 tentang Pedoman Pengusahaan Pertambangan Minyak Bumi pada Sumur Tua. Dengan diterbitkannya Peraturan Menteri Energi dan Sumber Daya Mineral Nomor 01 Tahun 2008, maka kegiatan penambangan, penyulingan, pengangkutan dan penjualan minyak mentah yang dilakukan masyarakat penambang di Desa Wonocolo adalah melanggar dan bertentangan dengan Peraturan Menteri tersebut.

\section{Usulan Penyelesaian Sengketa}

Untuk menyelesaikan sengketa pengelolaan penambangan minyak di Desa Wonocolo antara warga Desa Wonocolo dan KUD Bogo Sasono mitra kerja PT. Pertamina EP. Field Cepu Region Jawa, diusulkan penyelesaian sebagai berikut:

1. Pihak pemerintah, dalam hal ini PT. Pertamina EP. Cepu dan Pemerintah Kabupaten Bojonegoro, melakukan sosialisasi peraturan perundangan yang 
terkait dengan kegiatan penambangan. Sosialisasi dilakukan secara formal maupun informal melalui orang-orang yang disegani oleh masyarakat.

2. Agar tidak menyimpang dari UUD 1945, pengelolaan oleh masyarakat harus diadopsi oleh institusi yang merepresentasikan kedaulatan Negara atas penambangan sumur minyak di Desa Wonocolo, dengan alternatif cara:

a. Mengoptimalkan kembali peran KUD Bogo Sasono

b. Membentuk BUMD sesuai peraturan yang berlaku (Peraturan Menteri ESDM No. 01 Tahun 2008 Pasal 2 ayat 3).

c. Menegakkan hukum khususnya untuk mengatasi penyulingan ilegal, angkutan minyak mentah ke luar desa, dan penjualan minyak mentah kepada pengecer maupun pengepul.

3. Dikaitkan dengan Undang-undang Nomor 30 Tahun 1999 tentang Arbitrase, para pihak yang bersengketa atau berbeda pendapat, dalam hal ini KUD Bogo sasono mitra kerja PT. Pertamina EP Cepu dan masyarakat penambang Desa Wonocolo, disarankan melakukan penyelesaian di luar pengadilan melalui konsultasi, negosiasi, mediasi, konsiliasi, atau penilaian ahli melalui musyawarah untuk mendapatkan kompensasi biaya ongkos angkat dan angkut yang dapat diterima dan menguntungkan kedua belah pihak.

4. Dikaitkan dengan Undang-undang Nomor 22 Tahun 2001 tentang Minyak dan gas Bumi, hal yang harus dilakukan adalah:

a. Meyakinkan masyarakat khususnya masyarakat Desa Wonocolo, bahwa mereka harus tunduk pada peraturan yang berkaitan dengan eksplorasi, eksploitasi, pengolahan, pengangkutan dan penjualan minyak bumi.

b. Memberikan insentif atau biaya ongkos angkat dan angkut yang layak agar masyarakat penambang di Desa Wonocolo bersedia menyetorkan minyak mentahnya kepada KUD Bogo Sasono mitra kerja PT. Pertamina EP Cepu.

c. Kegiatan usaha hulu dan hilir harus dilakukan oleh institusi yang berhak mengelolanya sesuai dengan Pasal 9 Undang-undang Nomor 22 Tahun 2001. Karena itu masyarakat harus dihimpun agar bersedia menjalankan kegiatan pengelolaan minyak sumur tua melalui salah satu institusi yang telah ditetapkan undang-undang ini. 
5. Sebagai pelaksanaan dari Peraturan Menteri ESDM No. 01 Tahun 2008, perlu dilakukan persuasi dan negosiasi mengenai ongkos angkat dan angkut hasil produksi minyak mentah agar mereka bersedia menyetorkan kepada KUD Bogo Sasono, dengan menyadari bahwa sumberdaya alam harus digunakan sebesarbesarnya untuk kepentingan dan kesejahteraan rakyat sesuai amanat Pasal 33 ayat 2 UUD 1945; bukan untuk kepentingan sekelompok masyarakat.

6. Untuk memutus jalur penambang ke pihak luar (penyuling, pengecer, pengepul) diperlukan penegakan hukum yang tegas. Untuk itu perlu dilakukan kerjasama yang saling mendukung antara PT. Pertamina EP. Cepu, Pemerintah Kabupaten Bojonegoro, kepolisian. Penegakan hukum tidak hanya ditujukan kepada pelaksana kegiatan penyulingan, pengecer dan pengepul minyak ilegal, tetapi juga kepada pelindung kegiatan ilegal tersebut seperti preman dan oknum aparat yang membantu kegiatan ilegal tersebut.

\section{Kesimpulan}

Kesimpulan studi ini adalah:

1. Untuk membuat agar masyarakat memahami dan menyadari perlunya kepatuhan terhadap hukum, perlu dilakukan sosialisasi peraturan perundangan yang terkait dengan kegiatan penambangan yang dilakukan secara formal maupun informal melalui tokoh-tokoh masyarakat yang berpengaruh dan disegani masyarakat Desa Wonocolo.

2. Menyelesaikan sengketa mengenai ongkos angkat dan ongkos angkut minyak mentah antara warga setempat dan KUD Bogo Sasono selaku mitra kerja PT. Pertamina melalui penyelesaian di luar pengadilan.

3. Melakukan negosiasi biaya ongkos angkut berdasarkan pertimbangan kepentingan masyarakat luas, bukan kepentingan dan keuntungan sekelompok masyarakat.

4. Melakukan penegakan hukum yang tegas kepada penyuling, pengecer dan pengepul minyak mentah yang nyata-nyata telah melakukan kegiatan ilegal; serta memutus jalur penjualan minyak mentah dari penambang kepada penyuling, dari penyuling kepada pengecer dan pengepul. 


\section{Daftar Pustaka}

Marzuki, Peter, Mahmud, Prof. Dr. SH. MS. LLM. (2005). "Penelitian Hukum". Prenada Media Group. Jakarta.

(2009). "Pengkajian Dampak Pengelolaan Sumur Tua Secara Tradisional oleh Masyarakat di Wonocolo Field Cepu Region Jawa. Ditinjau dari Aspek Lingkungan, Sosial, Ekonomi, Hukum dan Politik". Kerjasama PT. Pertamina EP dengan Lembaga Penelitian dan Pengabdian Masyarakat (LPPM) ITS.

Undang-undang Dasar 1945

Undang-undang Nomor 1 Tahun 1970 tentang Keselamatan Kerja

Undang-undang Nomor 30 Tahun 1999 tentang Arbitrase dan Alternatif Penyelesaian Sengketa

Undang-undang Nomor 22 Tahun 2001 tentang Minyak dan Gas Bumi

Peraturan Pemerintah Nomor 82 Tahun 2002 tentang Pengelolaan Kualitas Air dan Pengendalian Pencemaran Air

Peraturan Menteri Energi dan Sumber Daya Mineral Nomor 01 Tahun 1008 tentang Pedoman Pengusahaan Pertambangan Minyak Bumi pada Sumur Tua 